\title{
A NEW STUDY METHOD OF MICROHABITAT STRUCTURE OF SMALL MAMMALS
}

\author{
CERQUEIRA, R. and FREITAS, S. R. \\ Departamento de Ecologia, Universidade Federal do Rio de Janeiro, C.P. 68020, \\ CEP 21941-590, Rio de Janeiro, RJ, Brazil \\ Correspondence to: Rui Cerqueira, Departamento de Ecologia, Universidade Federal do Rio de Janeiro, C.P. 68020, \\ CEP 21941-590, Rio de Janeiro, RJ, Brazil \\ Received October 08, 1997 - Accepted November 17, 1998 - Distributed June 30, 1999
}

\begin{abstract}
The variables in habitat studies are usually transformed in such a way that they become abstractions and intuition is lost. We tested a new method for the analysis of habitat using data collected in a grid laid at the "restinga de Maricá", in Rio de Janeiro State, Brazil. Thirty-seven microhabitat variables were measured at each trap station. We assume that these variables characterize the microhabitat structure at the moment when measurements were taken. The data are transformed in 3 ways: (1) the averages of the measured variables were calculated, as usual in habitat studies; (2) the data are transformed in densities per area in square meters without reduction in the number of variables; and (3) we calculated the natural logarithms of the data thus transformed. The 3 sets were analised through discriminant analysis. The logarithms of densities were the most efficient kind of transformation. This transformation resulted in a significance of $p=0.0001$ with $39.72 \%$ of variance in the $1^{\text {st }}$ discriminant function and of $\mathrm{p}=0.0426$ with $31.45 \%$ of variance in the $2^{\text {nd }}$ function, and $84.62 \%$ of groups correctly classified. We obtained better classification results than previous similar works and we kept the intuition through the data analysis.
\end{abstract}

Key words: discriminant analysis, methods, niche, neotropics, small mammals.

\section{RESUMO}

Um novo método de estudo da estrutura de microhábitat de pequenos mamíferos

As variáveis utilizadas em estudos de hábitat são transformadas de tal maneira que se tornam abstrações e se perde a intuição. Testamos um novo método para esse tipo de análise usando dados coletados em uma grade na restinga de Maricá, Rio de Janeiro. Em cada ponto de captura foram medidas 37 variáveis de microhábitat. Consideramos que tais variáveis caracterizam a estrutura dos microhábitats no momento em que são tomadas. Os dados foram transformados de 3 maneiras: (1) as médias das variáveis foram calculadas, como é usual em estudos de hábitat; (2) os dados foram transformados em suas densidades por área em metros quadrados, sem redução no número de variáveis; e (3) calculamos os logaritimos naturais dos dados transformados em densidades. Os 3 conjuntos foram submetidos à análise discriminante. O logaritimo das densidades foi o tipo de transformação mais eficiente. Esta transformação resultou na obtenção de $p=0,0001$, com 39,72\% da variância na $1^{\text {a }}$ função e um $p=0,0426$ com 31,45\% da variância na $2^{\text {a }}$ função, com um acerto de $84,62 \%$ na classificação dos grupos. Os resultados obtidos foram melhores do que em trabalhos similares anteriores, mantendo-se a intuição.

Palavras-chave: análise discriminante, métodos, nicho, pequenos mamíferos, Região Neotropical. 


\section{INTRODUCTION}

Several methods have been used in the studies of microhabitat choice by small mammals. Most studies use 2 basic aspects of vegetation that can be distinguished: structure or physiognomy, and floristics (Morrison et al., 1992). Many authors have used structural aspects in their studies of microhabitat choice (Cerqueira et al., 1994, Dueser \& Shugart, 1978; Ernest \& Mares, 1986; Murúa \& González, 1982), while others have used floristic aspects (Bonaventura et al., 1991, 1992) or both (Fa et al., 1990; Monamy, 1995). As Cerqueira (1995) has pointed out, floristics may be an indication of resources other than space, being a measure of niche not of habitat. Even some common habitat measurements as, for instance, litter, may be linked to niche in certain species (Freitas et al., 1997). The structural measures have different orders of magnitude and, therefore, are not very amenable to analysis and the data must be transformed before analysis. The most common methods of transformation are the use of means (Kelt et al., 1994), square-roots, natural logarithms or arcsine to normalise the data (Adler \& Wilson, 1987; Murúa \& González, 1982). Another problem is that the data are gathered using different unit systems and the results obtained are not intuitive. We describe here a method to avoid these problems (Cerqueira et al., 1994).

\section{MATERIAL AND METHODS}

We studied a 1 hectare grid with 100 traps evenly spaced. The area was described elsewhere (Cerqueira et al., 1990, 1994). We took 37 microhabitat measurements at each trap station, belonging to fourteen categories:

I. Canopy height $(\mathrm{CH})$ : estimate of canopy height taken at the trap station.

II. Woody species density (WD): wood plant species' richness, done by counting the woody species in a circle of $0.52 \mathrm{~m}$ radius at ground level.

III. Herbaceous species density (HD): similar to WD using herbaceous species.

IV. Woody stems density (WSD): number of woody stems in a $0.52 \mathrm{~m}$ radius at several heights. The measurement is taken turning a $0.52 \mathrm{~m}$ stick from an axis staked to the ground, at heights of $0.20 \mathrm{~m}, 0.40 \mathrm{~m}$, $0.60 \mathrm{~m}, 0.80 \mathrm{~m}, 1.00 \mathrm{~m}, 1.20 \mathrm{~m}, 1.40 \mathrm{~m}$, $1.60 \mathrm{~m}, 1.80 \mathrm{~m}$ and $2.00 \mathrm{~m}$, counting each live woody stem that touches the stick.

V. Herbaceous stem density (HSD): similar to WSD using live herbaceous stems.

VI. Horizontal obstruction estimate (HOE): vegetation cover in 3 height categories. The measurement is taken using a rectangle with $0.30 \mathrm{~m} \times 0.50 \mathrm{~m}$, divided into 32 equal small squares. This variable was measured in the following heights from the ground: $0.50 \mathrm{~m}, 1.00 \mathrm{~m}$, and $1.50 \mathrm{~m}$. The observer positions himself at $0.52 \mathrm{~m}$ from the trap station and he observes through the rectangle at each height. The retangle is positioned at north, south, east and west directions at each height. We counted the number of squares that were more than $50 \%$ obstructed by the vegetation.

VII. Soil surface exposure (SSE): the exposure is measured along two perpendicular transects $5.0 \mathrm{~m}$ long and $0.60 \mathrm{~m}$ wide at each trap station in an interval of every $0.50 \mathrm{~m}$ in each direction (north, south, east and west). We considered five soil surface exposure categories ( 0 to 4 ). The category zero corresponded a totally covered ground and the category four a completely open floor.

VIII. Soil litter density (LD): litter was collected at each trap station in a $11.56 \mathrm{~cm}$ radius circle $\left(0.042 \mathrm{~m}^{2}\right.$ area $)$. The litter was then ovendryed in a stove at $45^{\circ} \mathrm{C}$ during $48 \mathrm{~h}$, and weighed $\left(\mathrm{g} / \mathrm{m}^{2}\right)$.

IX. Distance to the closest trees (DIST): a measure of tree dispersion. We measured the distances to the closest trees in a 5.00 $\mathrm{m}$ radius circle from the trap station.

X. Mean diameter of the closest tree (DIA): diameters of the same last trees.

XI. Number of holes (HOL), number of hiding places (HID), number of trees with dead canopy (DC), number of stumps (STU), number of trees of diameter at breast high $\oplus 0.75 \mathrm{~m}(\mathrm{DBH})$ : all these measurements represent presumable hiding places for small mammals. Each measurement for each variable is taken in a $2.50 \mathrm{~m}$ diameter circle at the trap station. 
All variables were measured in the same trapping session within 8 days interval.

The measurements taken were transformed as 3 different sets of data. First, we used the usual procedure, calculating the mean value of each category (Table 1). We used the raw data of Litter Density (LD) and Canopy Height (CH). To prepare the $2^{\text {nd }}$ set we transformed each measurement as densities per square meter, excepting $\mathrm{CH}$ (Table $2)$. The $3^{\text {rd }}$ set was the same $2^{\text {nd }}$ set transformed in natural logarithms, as suggested by Digby \& Kempton (1987).

The data in each set was submitted to canonical discriminant analysis. The a priori groups were determined by the species trapped in each station during a period of 6 nights.

TABLE 1

Equations used for mean data transformation applied to each microhabitat variable.

\begin{tabular}{|l|l|l|}
\hline $\begin{array}{l}\text { Variable } \\
\text { WSD }\end{array}$ & $($ WSD0 + WSD20 + WSD40 + WSD60 + WSD80 + WSD100 + WSD120 + WSD140 + WSD160 + WSD180 + WSD200)/11 \\
\hline HSD & $($ HSD0 + HSD20 + HSD40 + HSD60 + HSD80 + HSD100 + HSD120 + HSD140 + HSD160 + HSD180 + HSD200)/11 \\
\hline SSE & SSE/4 \\
\hline HOE & $(\mathrm{HOE} 1+\mathrm{HOE} 2+\mathrm{HOE} 3) / 3$ \\
\hline DIA & $\mathrm{DIA} / 4$ \\
\hline DIST & $\mathrm{DIST} / 4$ \\
\hline $\mathrm{DBH}$ & $\mathrm{DBH} / 4$ \\
\hline HID & $((\mathrm{HOL} / 4+(\mathrm{EM} / 4)) / 2$ \\
\hline $\mathrm{STU}$ & $((\mathrm{DC} / 4)+(\mathrm{CE} / 4)) / 2$ \\
\hline $\mathrm{LD}$ & $\mathrm{LD} / 0.042$ \\
\hline
\end{tabular}

TABLE 2

Equations used for area data transformation applied to each variable. Each WSD and HSD heights and HOE obstructions had its own value.

\begin{tabular}{|l|l|}
$\begin{array}{l}\text { Variable } \\
\mathrm{WD}\end{array}$ & $\begin{array}{l}\text { Equation } \\
\mathrm{WD} / 0.849\end{array}$ \\
\cline { 3 - 3 } $\mathrm{WSD}$ & $\mathrm{WSD} / 0.849$ \\
$\mathrm{HD}$ & $\mathrm{HD} / 0.849$ \\
\hline $\mathrm{HSD}$ & $\mathrm{HSD} / 0.849$ \\
\hline $\mathrm{SSE}$ & $(\mathrm{SSE} / 20) / 5.09$ \\
\hline $\mathrm{HOE}$ & $((\mathrm{HOE} * 0.0049) * 33.06) / 8.32$ \\
\hline $\mathrm{DIA}$ & $\mathrm{DIA} / 4$ \\
\hline $\mathrm{DIST}$ & $\mathrm{DIST} / 4$ \\
\hline $\mathrm{DBH}$ & $\mathrm{DBH} / 19.63$ \\
\hline $\mathrm{HID}$ & $((\mathrm{HOL} / 19.63)+(\mathrm{EM} / 19.63)) / 2$ \\
\hline $\mathrm{STU}$ & $((\mathrm{DC} / 19.63)+(\mathrm{CE} / 19.63)) / 2$ \\
\hline $\mathrm{LD}$ & $\mathrm{LD} / 0.042$ \\
\hline
\end{tabular}

The groups so formed were named after the species caught: (1) no mammals, trap station without captures; (2) Philander, points that captured the marsupial Philander frenata; (3) Akodon (after Akodon cursor); (4) Metachirus (after Metachirus nudicaudatus); (5) Trinomys (after Trinomys eliasi); and (6) Didelphis (after Didelphis aurita).

\section{RESULTS}

The classification results were similar in spite the kind of transformation used (Table 3). However, only the logarithm set was the only one that produced significant functions. It had as well a set of variables correlated with the functions (Table 4). 


\section{DISCUSSION}

Multivariate data analysis have been in use in habitat studies since the pioneer work by Cody (1968). However, this approach has been criticised on several grounds, both mathematical and biological (James \& Culloch, 1990). A variety of methods of measurement has been in use for mammals. Nevertheless, few studies showed as the measurements were done (Dueser \& Shugart, 1978; Kelt, 1996; Yahner, 1986).

The data are always transformed or reduced but few studies show how the transformation was done (Adler \& Wilson, 1987; Murúa \& González 1982; Yahner, 1986).

Therefore, it is usually impossible to compare studies or to have even a glimpse on what are the authors talking of.

TABLE 3

Canonical discriminant functions, its significance and classification in all kinds of data transformations $(* \mathbf{p}<\mathbf{0 . 0 5})$.

\begin{tabular}{|c|c|c|c|c|c|c|c|c|}
\hline $\begin{array}{c}\text { Data } \\
\text { transformation }\end{array}$ & Function & Eigenvalue & $\begin{array}{c}\text { Relative } \\
\text { variance (\%) }\end{array}$ & $\begin{array}{c}\text { Cumulative } \\
\text { variance (\%) }\end{array}$ & $\begin{array}{c}\text { Wilk's } \\
\text { lambda }\end{array}$ & Significance & Classification \\
\cline { 2 - 3 } \cline { 5 - 7 } Mean & 1 & 0.90324 & 32.32 & 32.32 & 0.1136735 & 0.6464 & $80.77 \%$ \\
\hline Mean and $\log _{\mathrm{e}}$ & 1 & 0.88141 & 30.62 & 30.62 & 0.1076117 & 0.5552 & $80.77 \%$ \\
\hline Area & 1 & 0.90324 & 32.32 & 32.32 & 0.1136735 & 0.6464 & $80.77 \%$ \\
\hline Area and $\log _{\mathrm{e}}$ & 1 & 2.02931 & 39.72 & 39.72 & 0.0388115 & $0.0001 *$ & $84.62 \%$ \\
\hline & 2 & 1.60672 & 31.45 & 71.16 & 0.1175723 & $0.0426 *$ & \\
\hline
\end{tabular}

TABLE 4

Significant variables $(p<0.05)$ by univariate ratio $F$ and Wilk's lambda in discriminant analysis using each transformation.

\begin{tabular}{|c|c|c|c|c|}
\hline Data & Variable & Wilk's lambda & $\mathbf{F}$ & Significance \\
\hline Mean and $\log _{\mathrm{e}}$ & LD & 0.80007 & 4.898 & 0.0005 \\
\hline \multirow[t]{7}{*}{ Area and $\log _{\mathrm{e}}$} & WSD40 & 0.88786 & 2.476 & 0.0372 \\
\hline & WSD60 & 0.82211 & 4.241 & 0.0016 \\
\hline & WSD120 & 0.75043 & 6.518 & 0.0000 \\
\hline & WSD140 & 0.86208 & 3.136 & 0.0114 \\
\hline & WSD160 & 0.87866 & 2.707 & 0.0246 \\
\hline & HSD160 & 0.89352 & 2.336 & 0.0476 \\
\hline & LD & 0.80007 & 4.898 & 0.0005 \\
\hline
\end{tabular}

We have chosen our measurements on naturalistic grounds trying to describe the more evident features of the "restinga". However, our $1^{\text {st }}$ studies had been disappointing (Carvalho-Huber, 1989) since we noticed a low correlation between variables and functions.

The simple transformations thus used not only get out the naturalist intuition, but the significance as well. We detected a possible cause, the change in the value of the measured variables through the time. Therefore, for the present report we measured all variables during the trapping. We describe the variation of habitat in time elsewhere (Freitas \& Cerqueira, submitted).

The data transformation with best performance was the logarithm transformation applied to area transformation. The main advantage of this transformation is an intuitive perception of numerical results: it is easier to understand and compare data that reads 25 herbaceous stems $/ \mathrm{m}^{2}$ 
than one wich reads a mean of 25 herbaceous stems in a site.

Moreover, area transformation is a solution to put all variables into one only metric system. Using the same data set, Cerqueira et al. (1994) achieved a significance of $\mathrm{p}=0.0325$ and classification of $60.69 \%$ at discriminant analysis using area transformation. We obtained most groups correctly classified $(84.62 \%)$ using also the logarithm of the area transformation.

When all species are analysed together, it is supposed that the factors that determine a species presence in a habitat are the same for all species. However, our results showed that different species are influenced by distinct habitat factors. These results suggest that the habitat choice must be studied for each species separately.

Acknowledgements - We would like to thank the people of the Laboratório de Vertebrados that helped us in the field work. The $1^{\text {st }}$ hints for transforming the variables were discussed with B. Carvalho, M. Cardoso, M. P. Soares, S. M. S. Guapyassú and P. S. D'Andrea. N. P. Barros and A. M. Marcondes gave technical and administrative help. The work was supported by grants from CAPES, CEPG/UFRJ, CNPq, FAPERJ, FINEP and FUJB/UFRJ.

\section{REFERENCES}

ADLER, G. H. \& WILSON, M. L., 1987, Demography of a habitat generalist, the white-footed mouse, in a heterogeneous environment. Ecology, 68: 1785-1796.

BONAVENTURA, S. M., PIANTANIDA, M. J. \& GURINI, L., 1992, Seleccion de habitat en roedores cricetidos del delta Bonaerense. Acta Cient. Venezol. (Zool.), 43: 373380 .

BONAVENTURA, S. M., PIANTANIDA, M. J., GURINI, L. \& SANCHEZ LOPEZ, M. I., 1991, Habitat selection in population of cricetine rodents in the region Delta (Argentina). Mammalia, 55: 339-354.

CARVALHO-HUBER, B. M., 1989, Microhábitats de uma comunidade de pequenos mamíferos na restinga de Barra de Maricá, RJ. Dissertação de Mestrado em Zoologia, Museu Nacional, UFRJ, Rio de Janeiro.

CERQUEIRA, R., 1995, Determinação de distribuições potenciais de espécies. pp. 141-161. In: P. R. Peres-Neto, J. L. Valentin \& F. A. S. Fernandez (orgs.), Tópicos em tratamento de dados biológicos. Programa de PósGraduação em Ecologia da Universidade Federal do Rio de Janeiro, Rio de Janeiro, 161p.

CERQUEIRA, R., FERNANDEZ, F. A. S., GENTILE, R., GUAPYASSÚ, S. M. S. \& SANTORI, R. T., 1994, Estrutura e variação da comunidade de pequenos mamíferos da restinga de Barra de Maricá, R.J. Anais do III Simpósio sobre Ecossistemas da Costa Brasileira, 3: 15-32, Academia de Ciências do Estado de São Paulo, São Paulo.
CERQUEIRA, R., FERNANDEZ F. A. S. \& QUINTELA, M. F. S., 1990, Mamíferos da restinga de Barra de Maricá, Rio de Janeiro. Papéis Avulsos Zool., 37: 141-157.

CODY, M. L., 1968, On the methods of resource division in grassland bird communities. Am. Nat., 102: 107-147.

DIGBY, P. G. N. \& KEMPTON, R. A., 1987, Multivariate analysis of ecological communities. Chapman \& Hall, London, 206p.

DUESER, R. D. \& SHUGART JR., H. H., 1978, Microhabitat in a forest floor small mammal fauna. Ecology, 59: 89-98.

ERNEST, K. A. \& MARES, M. A., 1986, Ecology of Nectomys squamipes, the neotropical water rat, in central Brazil: home range, habitat selection, reproduction and behaviour. J. Zool., 210: 599-612.

FA, J. E., LOPEZ-PANIAGUA, J., ROMERO, F. J., GOMEZ, J. L. \& LOPEZ, J. C., 1990, Influence of habitat characteristics on small mammals in a Mexican high-altitude grassland. J. Zool., 221: 275-292.

FREITAS, S. R., ASTÚA DE MORAES, D., SANTORI, R. T. \& CERQUEIRA, R., 1997, Habitat preference and food use by Metachirus nudicaudatus and Didelphis aurita (Didelphimorphia, Didelphidae) in a restinga forest at Rio de Janeiro. Rev. Brasil. Biol., 57: 93-98.

JAMES, F. C. \& McCULLOCH, C. E., 1990, Multivariate analysis in ecology and systematics: Panacea or Pandora's box? Ann. Rev. Ecol. Syst., 21: 129-166

KELT, D. A., 1996, Ecology of small mammals across a strong environmental gradient in southern South America. J. Mamm., 77: 205-219.

KELT, D. A., MESERVE, P. L. \& LANG, B. K., 1994, Quantitative habitat associations of small mammals in a temperate rainforest in southern Chile: empirical patterns and the importance of ecological scale. J. Mamm., 75: 890904.

MONAMY, V., 1995, Population dynamics of, and habitat use by, Australian native rodents in wet sclerophyll forest, Tasmania. II. Pseudomys higginsi (Rodentia: Muridae). Wildl. Res., 22: 661-667.

MORRISON, M. L., MARCOT, B. G. \& MANNAN, R. W., 1992, Wildlife-habitat relationships: concepts and applications. The University of Wisconsin Press, Madison, 364p.

MURUÁ, R. \& GONZÁLEZ, L. A., 1982, Microhabitat selection in two Chilean cricetid rodents. Oecologia, 52: 12-15.

YAHNER, R. H., 1986, Microhabitat use by small mammals in even-aged forest stands. Am. Midl. Nat., 115: 174-180. 